they are usually treated with aerosol-generating C-PAP therapy (ie, they occupy C-PAP beds). ${ }^{6}$

On February 25, the hygiene and epidemiology unit and the prevention-protection service began providing telematic training to all hospital workers. Related course work has been developed to address various issues. A preliminary lesson was prepared on the epidemiological occurrences related to $\beta$-coronavirus outbreaks, with specific references to SARS-CoV-2. Furthermore, specific instruction on the importance of hospital disinfection, hand hygiene, and the use of PPE, has been provided to all healthcare personnel (ie, physicians, nurses, cleaner workers, etc). Finally, additional technical training has been provided to maintenance workers responsible for aeraulic systems to enhance their performance quality during this pandemic.

In conclusion, the emergence of the COVID-19 pandemic has required synergic cohesion of the working group to define the principal risks for patients and healthcare workers and to implement preventive measures such as PPE and training courses. At the same time, rapid renovation work in a hospital nearing completion was undertaken to enlarge the ICU areas for patients with respiratory failure. Overall, the structural division into non-COVID and COVID areas could be the best precautionary strategy to avoid the infectious risk between patients and staff.

Acknowledgments. None.

Financial support. No financial support was provided relevant to this article.
Conflicts of interest. All authors report no conflicts of interest relevant to this article.

\section{References}

1. Novel coronavirus disease 2019 (COVID-19) pandemic: increased transmission in the EU/EEA and the UK, sixth update. European Centre for Disease Prevention and Control website. https://www.ecdc.europa.eu/sites/default/ files/documents/RRA-sixth-update-Outbreak-of-novel-coronavirus-disease2019-COVID-19.pdf. Published March 12, 2020. Accessed April 21, 2020.

2. The Lancet Infectious Diseases Editorial. COVID-19, a pandemic or not? Lancet Infect Dis 2020;20:383.

3. Epidemia COVID-19. Aggiornamento nazionale [in Italian]. Istituto Superiore di Sanità website. https://www.epicentro.iss.it/coronavirus/bollettino/ Bollettino-sorveglianza-integrata-COVID-19_2-aprile-2020.pdf. Published April 2, 2020. Accessed April 21, 2020.

4. Rational use of personal protective equipment for coronavirus disease 2019 (COVID-19). World Health Organization website. https://apps.who.int/iris/ bitstream/handle/10665/331215/WHO-2019-nCov-IPCPPE_use-2020.1-eng. pdf. Published February 27, 2020. Accessed April 21, 2020.

5. Respiratory protective devices-filtering half masks to protect against particles. BS EN 149:2001. Requirements, testing, marking. British Standards website. http://www.nobelcert.com/DataFiles/FreeUpload/EN\%20149-2001\%20plus \%20A1-2009.pdf. Published July 2002. Accessed April 21, 2020.

6. Miller SL, Clements N, Elliott SA, Subhash SS, Eagan S, Radonovich LJ. Implementing a negative-pressure isolation ward for a surge in airborne infectious patients. Am J Infect Control 2017;45:652-659.

\title{
Risk factors for severe COVID-19 illness in healthcare workers: Too many unknowns
}

\author{
Pandora L. Wander MD, MS ${ }^{1,2}$ (]), Marika Orlov MD, $\mathrm{PhD}^{2}$, Susan E. Merel MD ${ }^{1}$ and Daniel A. Enquobahrie PhD, MPH, MD ${ }^{3}$ \\ ${ }^{1}$ Division of General Internal Medicine, Department of Medicine, University of Washington, Seattle, Washington, ${ }^{2}$ Department of Veterans Affairs, VA Puget Sound \\ Health Care System, Seattle, Washington and ${ }^{3}$ Department of Epidemiology, University of Washington, Seattle, Washington
}

To the Editor-We were very interested to read the recent letter by Zhou et al, "Protecting Chinese Healthcare Workers While Combating the 2019 Novel Coronavirus." 1 We agree that everything possible should be done to protect healthcare workers (HCWs) from developing COVID-19. We agree with the recommendations of Zhou et al including the importance of increasing production of personal protection equipment (PPE), training HCWs in proper use, and maintaining a high clinical suspicion for COVID-19 even in patients without respiratory symptoms. In addition, we call for more research into the risk factors leading to severe illness among HCWs, defined as COVID-19 requiring hospitalization or admission to the intensive care unit. ${ }^{2}$ Research in this area is sorely lacking, limiting implementation of evidence-based practices. Despite being younger and healthier than the general population with COVID-19, HCWs have similar rates of severe illness. In China, the proportion of HCWs with severe

Author for correspondence: Pandora L. Wander, E-mail: author@institution.edu Cite this article: Wander Pandora L., et al. (2020). Risk factors for severe COVID-19 illness in healthcare workers: Too many unknowns. Infection Control \& Hospital Epidemiology, 41: 1369-1370, https://doi.org/10.1017/ice.2020.178 illness decreased from $45 \%$ in early January 2020 to $9 \%$ after February 1,3 likely reflecting more consistent adoption of appropriate infection-control practices, including the use of PPE. However, severe illness among HCWs continues to be reported, suggesting that the use of currently approved infection control processes do not entirely prevent severe COVID-19 among HCWs. To explore risk factors for severe COVID-19 in HCWs, we performed structured searches using a Twitter analytics tool (Tweet Archivist, Seattle, WA) to identify news stories reported before March 16, 2020, about HCWs with severe COVID-19related illness ( $\mathrm{n}=6$ cases) (Table 1$)$. In most of these articles, neither high-risk host factors nor a clear high-inoculum exposure was evident, but in a few reports, potential exposure to inocula containing a high viral load was reported, including potential exposures to virus in stool.

In $10 \%$ of cases, gastrointestinal symptoms precede fever or respiratory symptoms by $1-2$ days. ${ }^{4}$ Furthermore, $60 \%$ of samples from the toilet, sink and door handles of an individual with SARS$\mathrm{CoV}-2$ were positive for viral RNA, even though the individual reported respiratory symptoms but not diarrhea. ${ }^{5}$ For HCWs, contact with surfaces and/or patients with these symptoms 
Table 1. Healthcare Worker Cases of Severe COVID-19 Reported in the Media Before March 16, 2020

\begin{tabular}{|c|c|c|c|c|c|c|c|c|}
\hline $\begin{array}{l}\text { Case } \\
\text { No. }\end{array}$ & Age, y & Sex & Occupation & Location & Host Factors & Exposure Factors & Ref & $\begin{array}{l}\text { Hypothesized Mechanism of } \\
\text { Large-Inoculum Exposure }\end{array}$ \\
\hline 1 & 29 & $\mathrm{~F}$ & Gastroenterologist & $\begin{array}{l}\text { Wuhan, } \\
\text { China }\end{array}$ & $\begin{array}{l}\text { None } \\
\text { known }\end{array}$ & $\begin{array}{l}\text { Frequent bedside visits to } 76 \\
\text { year-old man with suspected } \\
\text { COVID-19, had symptoms } 5 \\
\text { days later; "took precautions" } \\
\text { to protect herself }\end{array}$ & 8 & $\begin{array}{l}\text { Virus in stool; whether } \\
\text { colonoscopy was done was } \\
\text { not reported }\end{array}$ \\
\hline 2 & 29 & $\mathrm{~F}$ & Nurse & $\begin{array}{l}\text { Wuhan, } \\
\text { China }\end{array}$ & $\begin{array}{l}\text { None } \\
\text { known }\end{array}$ & $\begin{array}{l}\text { Visited families of confirmed } \\
\text { cases, teaching how to } \\
\text { disinfect their homes; "took } \\
\text { precautions" to protect } \\
\text { herself }\end{array}$ & 8 & $\begin{array}{l}\text { Unknown, potentially could } \\
\text { have been exposed to large } \\
\text { inoculum cleaning stool or } \\
\text { other waste in homes of } \\
\text { confirmed cases }\end{array}$ \\
\hline 3 & 34 & $M$ & Ophthalmologist & $\begin{array}{l}\text { Wuhan, } \\
\text { China }\end{array}$ & $\begin{array}{l}\text { None } \\
\text { known }\end{array}$ & $\begin{array}{l}\text { Treated a patient with acute } \\
\text { angle-closure glaucoma }\end{array}$ & 9 & $\begin{array}{l}\text { Sustained, close contact } \\
\text { during angle-closure } \\
\text { glaucoma procedure }\end{array}$ \\
\hline 4 & $40-49$ & $M$ & ED physician & Washington & $\begin{array}{l}\text { None } \\
\text { known }\end{array}$ & $\begin{array}{l}\text { "Complied at all times with } \\
\text { appropriate PPE procedures" }\end{array}$ & 10,11 & Unknown \\
\hline 5 & 70 & M & ED physician & $\begin{array}{l}\text { Paterson, } \\
\text { New Jersey }\end{array}$ & Age & $\begin{array}{l}\text { "Leads his institution's } \\
\text { emergency preparedness" }\end{array}$ & 11 & Unknown \\
\hline 6 & 67 & $M$ & $\begin{array}{l}\text { General } \\
\text { practitioner }\end{array}$ & $\begin{array}{l}\text { Varese, } \\
\text { Italy }\end{array}$ & Age & $\begin{array}{l}\text { Quoted as saying, "We have } \\
\text { run out of masks, but we } \\
\text { don't stop. We are careful, } \\
\text { and we go on." }\end{array}$ & 12 & $\begin{array}{l}\text { Continued working without } \\
\text { PPE }\end{array}$ \\
\hline
\end{tabular}

Note. ED, emergency department; PPE, personal protection equipment.

could represent opportunities for high-inoculum exposure. During the SARS epidemic, SARS-CoV RNA was detected in stool in greater quantities than any other site, ${ }^{6}$ leading the World Health Organization to conclude that, "diarrhoea could still remain important for infectivity, regardless of its cause." Although SARS-CoV-2 RNA is readily found in stool, ${ }^{7}$ whether replicating virus is present is less clear. However, ACE2 receptors, which are used by the virus to infect cells, are present in the GI tract, ${ }^{7}$ making it plausible that the GI tract is an active site of viral replication. We therefore postulate that exposure to virus from high-viral load sites such as stool should be formally evaluated as an ongoing risk factor for severe COVID-19-related illness in HCWs. To facilitate research in this area and to ensure adequate power, we suggest that deidentified information about HCW cases be shared in national data repositories so that these and other risk factors can be assessed and the workforce can be adequately protected. In the meantime, institutions, if not already doing so, should screen for diarrheal symptoms.

Acknowledgments. None.

Financial support. No financial support was provided relevant to this article.

Conflicts of interest. Tweet Archivist is owned by Dr. Wander's family. All authors report no conflicts of interest relevant to this article.

\section{References}

1. Zhou P, Huang Z, Xiao Y, Huang X, Fan XG. Protecting Chinese healthcare workers while combating the 2019 novel coronavirus. Infect Control Hosp Epidemiol 2020 Mar 5 [Epub ahead of print]. doi: 10.1017/ice.2020.60.

2. Wu Z, McGoogan JM. Characteristics of and important lessons from the coronavirus disease 2019 (COVID-19) outbreak in China: summary of a report of 72,314 cases from the Chinese Center for Disease Control and Prevention. JAMA 2020 Feb 24 [Epub ahead of print]. doi: 10.1001/jama. 2020.2648

3. Novel Coronavirus Pneumonia Emergency Response Epidemiology Team. The epidemiological characteristics of an outbreak of 2019 novel coronavirus diseases (COVID-19) in China [in Chinese]. Zhonghua liu xing bing xue za zhi 2020;41:145-151.

4. Wang D, Hu B, Hu C, et al. Clinical characteristics of 138 hospitalized patients with 2019 novel coronavirus-infected pneumonia in Wuhan, China. JAMA 2020;323:1061-1069.

5. Ong SWX, Tan YK, Chia PY, et al. Air, surface environmental, and personal protective equipment contamination by severe acute respiratory syndrome coronavirus 2 (SARS-CoV-2) from a symptomatic patient. JAMA $2020 \mathrm{Mar}$ 4 [Epub ahead of print]. doi: 10.1001/jama.2020.3227.

6. Cheng PK, Wong DA, Tong LK, et al. Viral shedding patterns of coronavirus in patients with probable severe acute respiratory syndrome. Lancet 2004;363:1699-1700.

7. Ungaro RC, Sullivan T, Colombel J, Patel G. What should gastroenterologists and patients know about COVID-19? Clin Gastroenterol Hepatol 2020 [Epub ahead of print]. doi: 10.1016/j.cgh.2020.03.020.

8. Wee S, Wang V. Two women fell sick from the coronavirus, one survived. New York Times website. https://www.nytimes.com/interactive/2020/03/ 13/world/asia/coronavirus-death-life.html. Published March 13, 2020. Accessed April 24, 2020.

9. Buckley C. Chinese doctor, silenced after warning of outbreak, dies from coronavirus. New York Times website. 2020. https://www.nytimes. com/2020/02/06/world/asia/chinese-doctor-Li-Wenliang-coronavirus. html. Published February 6, 2020. Accessed April 24, 2020.

10. Green SJ, Clarridge C. EvergreenHealth doctor tests positive for coronavirus, in critical condition. Seattle Times website. https://www.seattletimes.com/ seattle-news/health/evergreenhealth-doctor-tests-positive-for-coronavirusin-critical-condition/. Published March 15, 2020. Accessed April 24, 2020.

11. Jaquis W. Two emergency physicians in critical condition. American College of Emergency Physicians website. https://www.acep.org/corona/ covid-19-articles/a-statement-from-acep-president-william-jaquis-md-facep/? utm_campaign=ACEP\&fbclid=IwAR2klgaE-UnRBqb6BbdyeCz0RQmTeY NguBTcgq7y0zsk6uitnQ0wVCKJxlI. Published March 16, 2020. Accessed April 24, 2020.

12. Frellick M. Colleagues mourn Italian 'hero' physician killed by COVID-19. Medscape website. https://www.medscape.com/viewarticle/926816?nlid=134 498_3901\&src=wnl_newsalrt_200313_MSCPEDIT\&uac $=139370 \mathrm{MJ} \&$ impID=2310754\&faf=1. Published March 16, 2020. Accessed April 24, 2020. 